\title{
THE EFFECT OF LEARNING STRATEGY AND LEARNING MOTIVATION ON STUDENT LEARNING OUTCOMES MADRASAH IBTIDAIYAH STATE 3 ACEH SOUTH
}

\author{
Fitri Wahyuni* \\ *Post Graduate of the FITK UIN SU Medan
}

\begin{abstract}
This study aims to find out: (1) the effect of the application of learning strategies on students' Fikih learning outcomes, (2) the effect of learning motivation on student Fikih learning outcomes, and (3) the interaction between learning strategies and learning motivation towards Fikih learning outcomes. The population of this study was all students in class $\mathrm{V}$ MIN 3 Aceh Tenggara consisting of 3 classes. Based on Cluster Random sampling techniques, one class as a collaborative learning class and one competitive learning class. The research instrument is a test used to obtain learning outcome data and questionnaires to obtain data on student learning motivation. The normality test of the learning outcome data is the Liliefors test and the homogeneity test is the Fisher test and the Bartlett test. The analysis technique is two-way Anova at significance $\alpha=0.05$ followed by the Scheffe test. The results showed: (1) the average learning outcomes of students taught with collaborative learning strategies $\bar{X}=$ 28.15 higher than the average learning outcomes of students taught with competitive learning strategies $\bar{X}=26.92$, with $\mathrm{F}_{\text {count }}=29.57>\mathrm{F}_{\text {table }}=$ 3.968 , (2) the average learning outcomes of students with high learning motivation $\bar{X}=29.93$ higher than the learning outcomes of students with low learning motivation $\bar{X}=25.94$ with $\mathrm{F}_{\text {count }}=4.43>\mathrm{F}_{\text {table }}=3.968$, and (3) there is an interaction between learning strategies and learning motivation towards Fikih learning outcomes with $\mathrm{F}_{\text {count }}=7.18>\mathrm{F}_{\text {table }}=3.968$.
\end{abstract}

\section{Keywords: Learning, Motivation, Learning Results}

\section{INTRODUCTION}

Learning is an activity carried out so that the behavior changes from not knowing to knowing in the learning self. Basically learning is an active process that requires encouragement and guidance towards the achievement of the desired goals. Learning brings changes to individuals who learn, these changes are not only about the amount of knowledge but also in the form of skills, habits, attitudes, regarding all aspects of a 
person's organism or person. The essence of learning is the change in behavior of the learner, from not knowing to knowing.

Jurisprudence is one part in achieving the goal of education to make humans who are (perfect). Education as a transfer of knowledge is the main spearhead in conveying the teachings contained in the Qur'an and Al-Hadith as the main sources of Islamic teachings. Where with this education, religious teachings can be passed on to the next generation and truly internalized in future generations.

Applying the right strategy the teaching material in Jurisprudence can be absorbed by the students as well as possible. The right strategy will determine the effectiveness and efficiency of learning. As a teacher educating Islamic religion it is necessary to know the strategies in learning Jurisprudence. By knowing these strategies, the teacher is expected to be able to convey the material of Islamic teachings with a variety of variations so that the objectives of Islamic religious education can be achieved more easily.

Students in implementing learning have different learning motivations from one another. But what is certain, every student desires to be able to achieve high learning outcomes and also have value benefits in his life. Therefore, every student has a directed motivation and encourages him to do something with all the abilities he has. With the motivation can be a driving force to carry out learning activities optimally.

Learners want to do a learning activity with all the effort that he has, because in that person there is such great strength and energy. Therefore, motivation is the psychological aspects possessed by each individual. Motivation is a power (power), power (forces), power (energy), or a complex state (a complex state) and preparedness (preparatory set) in an individual (organism) to move (to move, move, motive) in the direction of a particular goal, whether realized or not realized.

\section{THEORITICAL REVIEW}

Dimyati and Mudjiono (1999: 3) explain learning outcomes are the result of an interaction of learning and teaching. Djamarah and Zain (2002: 59) explain that learning outcomes are students' mastery of the material / subject matter that the teacher has provided when the teaching process takes place. 
Learning outcomes according to Gagne and Briggs as quoted by Sudjana (2002: 45) that can be grouped into five categories, namely intellectual skills, cognitive strategies, verbal information, motor skills and attitudes. in this case learning outcomes are obtained in the form of knowledge and skills. Rohani and Ahmadi (2005: 169) state that the assessment of learning outcomes aims to see the progress of student learning in terms of mastery of teaching material that has been learned in accordance with the objectives set.

Collaborative learning according to Jonassen (1996: 78) is a small group learning where students work together to maximize the results of their own learning and the learning outcomes of other group members. Gunawan (2004: 187) states that there are five important elements that must be present in collaborative learning, namely: (1) positive interdependence, namely (feelings of togetherness, (2) face to face interaction or face to face support each other (mutual help, mutual respect, congratulating and celebrating mutual success, (3) individual and group responsibility for learning success, (4) interpersonal communication skills and communication in a small group (communication, trust, leadership, decision making and management and conflict resolution), and (4) group processing (reflecting on their functions and abilities to work together as a group and how to be able to perform better).

The main characteristics of collaborative learning according to Davis (1993: 89) are as follows: (1) students work in teams to master subject matter, (2) teams or groups formed vary from students who have high, medium, and low academic performance, (3) tiim consists of members that vary in terms of sex, and race, and (4) the reward system is oriented towards groups, not individuals. Furthermore, Hill and Hill (1996: 78) state that there are two important elements that are always present in collaborative activities, namely equality of goals and positive interdependence.

Nasution (2000:87) explains how to adjust individual learning where competitive nuances take place, namely, students accept assignments that are completed according to their own pace, students are given additional assignments, students do things according to their interests and abilities.

The purpose of competitive learning as expressed by Johnson and Johnson (1996: 120) is to maximize the academic performance of each 
student in order to achieve the highest performance that may only be achieved by one or several students.

Schmuck \& Schmuck (2000: 78) states to achieve that goal students are encouraged to compete with the assumption that their classmates are rivals that must be defeated. Opportunities to compete individually can provide incentives and excitement for activities in the class, whether the competition is to get prizes and praise or just for satisfaction.

Regarding the implementation of competitive strategies, Johnson and Johnson (1997: 96) state that the application of competitive strategies in schools is based on several assumptions that resemble myths: (1) our society currently lives in a very competitive situation and students must be educated to compete so that they can survive in competitive situations, (2) achievement, extraordinary performance, the emergence of great leaders, encouragement, ambition, and motivation are very dependent on how far a person competes with others, (3) competition can build character that tough and strengthen life in the real world, (4) students prefer the atmosphere of competition, and (5) competition can increase self-confidence and self-esteem.

Purwanto (2000:67) states that a motive is a conflicting statement in an organism that directs the behavior and actions of an organism that leads to a goal or incentive. Smittle (2003: 11) explains motivation as a condition in a person who drives an individual's desire to carry out certain activities to achieve goals.

Sardiman (2011: 73) explains the motive can be said as a driving force from within and within the subject to carry out certain activities in order to achieve a goal. Even motives can be interpreted as an internal condition in the form of preparedness.

Hamalik (2003: 158) states that there are two principles that can be used to review motivation: (1) motivation is seen as a process. Knowledge of this process will help explain the observed behavior and to estimate other behaviors in a person, and (2) determine the character of this process by looking at the clues of his behavior. Whether the clues can be trusted, their usefulness in estimating and explaining other behavior can be seen.

Learning motivation greatly affects students in increasing their willingness and enthusiasm to learn in achieving a goal with indicators of learning motivation are: (1) expectations for success in learning, (2) desire to learn, (3) encouragement to succeed, and (4) enthusiasm achievers. 


\section{METHODS}

This research was conducted at Madrasah Ibtidaiyah Negeri Aceh Tenggara. When this research was conducted in the even semester of the 2018-2019 school year. The method used in this study is a quasiexperimental method. This method was chosen because the class used for treatment both for collaborative learning classes and competitive learning classes is a pre-formed class and the characteristics of students being controlled are learning motivation. The study population was all students of class V Madrasah Ibtidaiyah Negeri 3 Aceh Tenggara which consisted of 3 classes. The sampling technique is cluster random sampling. Based on Cluster Random sampling techniques, one class as a collaborative learning class and one competitive learning class. The research instrument is a test used to obtain learning outcome data and questionnaires to obtain data on student learning motivation. The normality test of the learning outcome data is the Liliefors test and the homogeneity test is the Fisher test and the Bartlett test. The analysis technique is two-way Anova at significance 0.05 followed by the Scheffe test.

\section{RESEARCH RESULTS AND DISCUSSION}

Collaborative learning strategies are proven to be effective in improving overall learning outcomes of Islamic Jurisprudence in Southeast Aceh Madrasah 3 students both for groups of students with high learning motivation and low learning motivation. From these findings it is shown that to teach Jurisprudence material is more effective using collaborative learning strategies than with competitive learning strategies.

Teachers are expected to have the ability to create a learning atmosphere that is fun and meaningful. To create a pleasant and meaningful atmosphere is not easy. Therefore knowledge and skills are needed on how to create a pleasant and meaningful classroom atmosphere. One of them is the use of appropriate learning strategies. The use of learning strategies is inseparable from the characteristics of students. Because if the teacher knows the characteristics of each student then the teacher will know the right learning strategy that will be used. If the teacher can implement the learning strategy appropriately and know the characteristics and needs of students, it can improve student learning outcomes. 
Collaborative learning strategy is a strategy in learning in the form of learning groups that work together. Therefore, in collaborative learning interaction, cooperation and mutual need occur among the members of the learning group. The measure of success is determined based on the extent to which the study group achieved the goal. In this activity, cooperation, personal responsibility and mutual support are needed because the success of the group is determined by the success of the individual members involved in it.

On the other hand, competitive learning strategies strongly emphasize personal effort to achieve the goals set. Interaction between friends is very less and each individual is oriented towards achieving maximum results. The assessment and reward system becomes a reference for determining the loss and loss of a person in achieving the targets set.

In the implementation of Jurisprudence by implementing collaborative learning strategies, the teacher's role is to facilitate the division of learning groups, giving group assignments which of course begin with the presentation of important points of teaching material. Then the students then interact in their groups and create positive interdependence among students, the division of work and responsibilities are well established.

Whereas in the implementation of Jurisprudence by implementing competitive learning strategies the teacher's role is the main deliverer of teaching material then students are given individual assignments. During the learning process individually students work preparing their assignments. Therefore there is less interaction between students and there is no division of labor, so the work of students is individual work. Therefore for students who are smart do not experience difficulties in completing these tasks, while for students who are slow will certainly have difficulty in completing assignments.

Collaborative learning strategy is a strategy in learning in the form of learning groups that work together. Therefore, in collaborative learning interaction, cooperation and mutual need occur among the members of the learning group. The measure of success is determined based on the extent to which the study group achieved the goal. In this activity, cooperation, personal responsibility and mutual support are needed because the success of the group is determined by the success of the individual members involved in it. 
Meanwhile the competitive learning strategy strongly emphasizes personal effort to achieve the goals set. Interaction between friends is very less and each individual is oriented towards achieving maximum results. The assessment and reward system becomes a reference for determining the loss and loss of a person in achieving the targets set.

Learning motivation is significant enough to distinguish student learning outcomes, where student learning outcomes with high learning motivation both those taught with collaborative learning strategies and competitive learning strategies are better than student learning outcomes with low learning motivation. The role of motivation with the success of students of Madrasah Ibtidaiyah Negeri 3 Aceh Tenggara in learning is very close and inseparable. The higher the motivation to learn a student, the greater the effort he does to achieve successful learning. Because motivation in a person becomes a mover (motor) that will activate all energy, including learning activities. Thus, it can be stated that learning motivation has a positive and significant relationship with student learning outcomes.

The results turned out to show all the research hypotheses, namely: (1) the learning outcomes of Jurisprudence students of Madrasah Ibtidaiyah Negeri 3 Aceh Tenggara taught with collaborative learning strategies higher than the learning outcomes of students of Madrasah Ibtidaiyah Negeri 3 Aceh Tenggara who were taught with competitive learning strategies, (2) Jurisprudence study results of students of Madrasah Ibtidaiyah Negeri 3 Aceh Tenggara with high learning motivation are higher than the learning outcomes of Jurisprudence Students of Madrasah Ibtidaiyah Negeri 3 Aceh Tenggara with low learning motivation, and (3) there is an interaction between learning strategies and learning motivation gives an influence on the results studying Jurisprudence students of Madrasah Ibtidaiyah Negeri 3 Aceh Tenggara, all three can be accepted.

The findings of this study support previous research findings including: (1) Tint and Nyunt's (2015) research shows collaborative learning enables students to do their exercises on the web as individuals or with their peers according to the teacher's direction using think-pairshare techniques. In addition, the ability of students to make decisions also increases in learning that uses collaborative learning in virtual classroom activities, (2) research by Dewi, Mudakir, Murdiyah (2016) shows that the collaborative learning model based on lesson study has a significant effect 
with a probability of $(\mathrm{p}=0,000)$ on the critical thinking of students with an average critical thinking ability of the experimental class at $72.56( \pm 10.16)$ while the critical thinking ability of the control class is $60.52( \pm 11.96)$. In the experimental class has high critical thinking ability criteria while the control class has low critical thinking ability criteria, (3) Ni'matuzahroh research (2015) shows an increase in reading comprehension after being given a collaborative reading strategy and the strategy is effective in increasing students' reading comprehension.

Students in implementing learning have different learning motivations from one another. But what is certain, every student desires to be able to achieve high learning outcomes and also have value benefits in his life. Therefore, every student has a directed motivation and encourages him to do something with all the abilities he has. With the motivation can be a driving force to carry out learning activities optimally.

Learners want to do a learning activity with all the effort that he has, because in that person there is such great strength and energy. Therefore, motivation is the psychological aspects possessed by each individual. Motivation is a power (power), power (forces), power (energy), or a complex state (a complex state) and preparedness (preparatory set) in an individual (organism) to move (to move, move, motive) in the direction of a particular goal, whether realized or not realized.

The teacher's role is to constantly develop students' learning motivation optimally in the learning process. Because in each student stored strength (power), power (forces), power (energy), or a complex state (a complex state) and preparedness (preparatory set) in an individual (organism) to move (to move, motion, motive) to carry out learning activities.

The position of motivation with the success of a student in learning is very close and inseparable. The higher the motivation to learn a student, the greater the effort he does to achieve successful learning. Because motivation in a person becomes a mover (motor) that will activate all energy, including learning activities. Thus, it can be stated that learning motivation has a positive and significant relationship with student learning outcomes.

The overall data analysis results obtained by the average learning outcomes of Islamic Jurisprudence students in Southeast Aceh 3 with high motivation to learn better than the results of Jurisprudence students with low learning motivation. This indicates that students with high learning 
motivation on average have better fiqh learning outcomes compared to students with low learning motivation. Thus students with high learning motivation understand and master the subject matter of Jurisprudence compared to students with low learning motivation.

This is in line with the explanation of Hamalik (2004: 161) which states that the function of motivation is: (1) encouraging behavior or deeds. Without motivation there will be no action, for example learning, (2) motivation functions as a guide, meaning directing the action to achieve the desired goals, and (3) motivation functions as a mobilizer, meaning moving one's behavior. The size of the motivation will affect how quickly a job / task can be completed properly.

The findings of this study support previous research including: (1) Mappease research (2009) found there was a positive influence of learning motivation on the learning outcomes of Grade III students of the Department of Electricity at SMK Negeri 5 Makassar based on a questionnaire showing that the learning outcomes variable $(Y)$ was in the medium category by $73 \%$. This is evidenced that there are 10 people or $23 \%$ are in the very high category, $0 \%$ in the high category or in other words there are no learning outcomes in the high category, there are $32 \%$ or $73 \%$ are in the moderate category, and there are 2 people or $5 \%$ in the low category, (2) Suprihatin research (2015) concluded that to foster student motivation is one of the techniques in developing the ability and willingness to learn. One logical way to motivate students in learning is to relate learning experiences to student motivation, and (3) Nurdin's research results (2015) show learning motivation has a relationship with learning citizenship education. The coefficient of determination $\left(R_{2}\right)$ of 0.504 means that $50.4 \%$ learning motivation has a relationship to the learning achievement of citizenship education, while the remaining $49.6 \%$ $(100 \%-50.4 \%)$ is influenced by other factors. This can be seen from the results of $t_{\text {count }}=7.933>t_{\text {table }}$ value at $5 \%=1.670$.

The third hypothesis testing there is an interaction between learning strategies and learning motivation in influencing the learning outcomes of Islamic Jurisprudence students of Southeast Aceh State Islamic School 3. When seen the average learning outcomes of Jurisprudence in groups of students with high learning motivation taught with collaborative learning strategies higher than the average learning outcomes of Jurisprudence groups of students with low learning motivation and taught with competitive learning strategies. 
The average learning outcomes of Jurisprudence in groups of students of Madrasah Ibtidaiyah Negeri 3 Aceh Tenggara with low learning motivation taught with collaborative learning strategies are lower than the average learning outcomes of Jurisprudence groups of students of Madrasah Ibtidaiyah Negeri 3 Aceh Tenggara with low learning motivation taught with competitive learning strategy.

This means that for groups of students with high learning motivation it is better to use collaborative learning strategies while students with low learning motivation are better taught by using competitive learning strategies. Thus it can be concluded that the learning strategy and learning motivation significantly influence the learning outcomes of Islamic Jurisprudence Students in Southeast Aceh 3 Madrasah.

This is possible because through collaborative learning: (1) students practice integrating concepts obtained from instructors' explanations or from books / readings with their application in daily life, (2) students are given the opportunity to look for information outside the classroom both information that is nature objects / readings, visions (competitive objects, $\mathrm{TV} /$ radio / internet) or people/experts or figures, (3) students make alternatives to overcome the topics / objects discussed, (4), students make decisions (according to their abilities) that relating to the concepts that have been learned by considering the values that exist in society, (5) formulating steps that will be taken to overcome the problem and prevent the emergence of problems related to the topics discussed.

\section{CONCLUSIONS}

The conclusions of the study are: (1) the average learning outcomes of Southeast Aceh 3 Aceh Southeast Aceh Madrasah Ibtidaiyah students taught with collaborative learning strategies are higher than the average learning outcomes of the Jurisprudence students of the Southeast Aceh State Islamic School 3 Ibtidaiyah taught with competitive learning strategies, (2) the average learning outcomes of Jurisprudence Madrasah Ibtidaiyah State 3 students in Southeast Aceh with higher learning motivation is higher than the average learning outcomes of Jurisprudence Students of Madrasah Ibtidaiyah Negeri 3 Southeast Aceh with low learning motivation, and (3) there is an interaction between learning strategies with learning motivation, where students with high learning motivation are more precisely taught using collaborative learning 
strategies, whereas Madrasah Ibtidaiyah Negeri 3 Aceh Tenggara students with low learning motivation are more precisely taught with competitive learning strategies.

\section{RECOMMENDATIONS}

The recommendations submitted as follows: (1) teachers as learning designers are advised to pay attention to the characteristics of students in threatening learning so that teachers can determine the choice of learning strategies that are more appropriate to be implemented because learning strategies and student characteristics are a component that can determine and influence learning outcomes . (2) teachers in learning activities need to apply collaborative learning strategies in Jurisprudence learning, because collaborative learning strategies provide higher learning outcomes in Jurisprudence subjects compared to competitive learning strategies, and (3) other studies are recommended for other researchers to apply the strategy collaborative learning and competitive learning in other fields of study and not only in the cognitive domain,

\section{REFERENCES}

Davis, A. (1993) Colaborative Learning. http://www. wcer.wisc.edu/archie/ cli/cl/ doingclk/DCL1.asp.

Davies, Ivor K. (2001) The Management of Learning. Diterjemahkan ke dalam Bahasa Indonesia oleh Sudarsono Sudirjo dkk. Cetakan Kedua. Jakarta: Rajawali bekerjasama Dengan Pusat Antar Universitas di Universitas Terbuka.

Dimyati dan Moedjiono. (1999) Belajar dan Pembelajaran, Jakarta: Rineka Cipta.

Djamarah, Syaiful Bahri dan Zain, Ahmad. (2002) Strategi Belajar Mengajar. Jakarta: Rineka Cipta.

Gunawan, Adi. W. (2004) Genius Learning Strategi. Jakarta: Grasindo.

Hamalik, Oemar. (2004) Proses Belajar Mengajar. Jakarta: Bumi Aksara.

Hill, S. dan Hill, T. (1996) The Collaborative Classroom, A Guide to Cooperative Learning. Armadale Vic: Eleanor Curtain Publishing.

Johnson, D. W. dan Johnson, F.P. (1997) Joining Together, Group Theory and Group Skills. Boston: Allyn and Bacon.

Jonnasen, D.H.. (1996) Handbook of Research for Educational Communications and Technology. New York: MacMillan Library Reference USA. 
Purwanto, M. Ngalim. (2006) Psikologi Pendidikan. cetakan kelima. Bandung: Remaja Rosdakarya.

Rohani, Ahmad dan Ahmadi, Abu. (2005) Pengelolaan Pengajaran. Jakarta: Rineka Cipta.

Rusydi Ananda dan Muhammad Fadli. (2018) Statistik Pendidikan. Teori dan Praktek Dalam Pendidikan. Medan, Widya Puspita.

Sardiman A.M. (2011) Interaksi dan Motivasi Belajar Mengajar. Cetakan kedua. Jakarta: Raja Grafindo Persada.

Schmuck, R.A. dan Schmuck, P.A. (1980) Group Processes in the Classroom. Dubuque, Iowa: WM. C. Brown.

Sudjana, Nana. (2002) Dasar-Dasar Proses Belajar Mengajar. Jakarta; Sinar Baru Algensindo. 